Chirurgia (2019) 114: 630-638

No. 5, September - October

Copyright@ Celsius

http://dx.doi.org/10.21614/chirurgia.114.5.630

\title{
Pancreatic Neuroendocrine Tumors - Case Series and Literature Review
}

\author{
Octavian Mihalache ${ }^{1,2}$, Horia Doran ${ }^{1,2}$, Cătălina Poiană ${ }^{1,3}$, Andra Bîrligea $^{2}$, Mihai Octavian Cîrstea ${ }^{2}$, \\ Traian Pătrașcu' ${ }^{1,2}$
}

"'Carol Davila" University of Medicine and Pharmacy, Bucharest, Romania

${ }^{2}$ Surgical clinic I Juvara Clinical Hospital Dr. I. Cantacuzino Bucharest, Romania

${ }^{3}$ National Institute of Endocrinology C. I. Parhon, Bucharest, Romania

\section{Corresponding author: \\ Associate Professor Horia Doran \\ "Carol Davila" University of Medicine and Pharmacy \\ "Dr. I. Cantacuzino" Clinical Hospital \\ $1^{\text {st }}$ Surgical Department \\ Bucharest, Romania \\ E-mail: doranh2003@yahoo.com}

Abbreviations:

NETs - Neuroendocrine tumors;

PNETS - Pancreatic Neuroendocrine Tumors;

PP - Pancreatic Polypeptide;

CGA - Chromogranin A;

NSE - Neuron-Specific Enolase;

CT - Computed Tomography;

MRI - magnetic resonance imaging.

\section{Rezumat \\ Tumorile pancreatice neuroendocrine - serie de cazuri și sinteză a literaturii}

Introducere: Tumorile neuroendocrine (TNE) sunt un grup heterogen de tumori cu manifestări clinice diferite şi comportament biologic divers. Localizarea pancreatică este una dintre cele mai frecvente pentru tumorile neuroendocrine. Deşi sunt considerate tumori relativ rare, studii mai recente asupra epidemiologiei TNE au demonstrat o incidență şi o prevalență crescândă în ultimii 30 de ani.

Scop: Am încercat să comparăm strategia terapeutică într-un mediu clinic real şi modelul ideal din literatură.

Materiale şi Metode: Seria noastră de cazuri constă în 18 pacienți diagnosticați cu tumori pancreatice neuroendocrine pe o perioadă de 10 ani (2009-2018) internați şi tratați în secția Chirurgie I a Spitalului Clinic Dr. I. Cantacuzino. Cazurile au fost analizate retrospectiv privind particularitățile de diagnostic şi alegerea tratamentului urmată de prezentarea datelor din literatură.

Rezultate: Dintre cele 18 cazuri 13 au avut tumori functionale (11 insulinoame şi 2 gastrinoame), iar 5 tumori nefunctionale. Majoritatea tumorilor au fost localizate în coada pancreasului (12 cazuri), celelalte au fost localizate în corp (1 cazuri) şi în capul pancreasului (5 cazuri). Tratamentul chirurgical a constat în 10 enucleări (dintre care 3 pe cale laparoscopică) şi 8 rezecții pancreatice, 2 dintre ele asociate cu splenectomie şi, într-un caz, a fost efectuată şi o metastazectomie hepatică. Urmărirea medie a fost de 12 luni. Nu s-au înregistrat recurențe locale sau la distanță 
cu o singură excepție, o femeie care s-a prezentat după un an cu o tumoră cefalo-pancreatică care s-a dovedit a fi un adenocarcinom.

Concluzii: Diagnosticul TNEP poate fi dificil chiar şi în prezența unui sindrom de hipersecreție hormonală. Imagistica nucleară cu octreotid este utilă atât pentru localizarea tumorii şi, de asemenea, cât şi pentru a detecta eventuale tumori oculte care nu au fost evidențiate de explorările conventionale. Toate tumorile neuroendocrine pancreatice ar trebui considerate potential maligne şi ar trebui evitată în mod special utilizarea termenului „benign”, de aceea gradul de diferențiere al tumorii trebuie stabilit pe baza numărului mitotic şi a indicelui Ki-67. Tratamentul chirurgical rămâne singurul cu potențial curativ.

Cuvinte cheie: tumori pancreatice neuroendocrine, insulinom, tumori neuroendocrine nefuncționale

\begin{abstract}
Background: Neuroendocrine tumors (NETs) are a heterogeneous group of tumors with various clinical manifestations and biological behavior. Among the most common neuroendocrine tumors (NETs) are pancreatic neuroendocrine tumors (PNETs). They are considered to be relatively rare tumors; however, more recent studies on NET epidemiology have demonstrated an increasing incidence and prevalence over the past 30 years.

Aims: We intend to compare the strategy used in a real life clinical environment in the case of pancreatic neuroendocrine tumors, as opposed to an ideal model, as presented in literature.

Materials and methods: Our case series consist in 18 patients with neuroendocrine pancreatic tumors diagnosed and treated in the Surgery I department of Clinical Hospital Dr. I. Cantacuzino over a 10-year period (2009-2018). We made a retrospective analysis of these patients, of their diagnosis particularities and choice of treatment and a review of the literature.

Results: Out of these 18 cases, 13 had functioning tumors (11 insulinomas and 2 gastrinomas) and 5 non-functioning tumors. Most of the tumors were located in the tail of the pancreas (12 cases) the others were located in the body ( 1 cases) and the head of the pancreas (5. cases). Surgical treatment consisted in 10 enucleations (3 of them laparoscopic) and 8 pancreatic resections, 2 of them associated with splenectomy and in one case a liver metastasectomy was also performed. The mean follow-up was 12 months. No local or distant recurrences were found with one exception, one female which presented after one year with a cephalic pancreatic tumor that proved to be an adenocarcinoma.

Conclusions: Diagnosis of PNETs may be difficult even in the presence of a hormonal hypersecretion syndrome. Nuclear imaging with octreotide is useful for locating the tumor and also for the detectionof any possible occult tumors which cannot be identified through the use of conventional imaging. All PNETs should be considered as potentially malignant, and the use of the term "benign" should be particularly avoided, which is why tumor grading based on the mitotic count and Ki-67 index must be established for every case. Surgical treatment remains the only with curative potential
\end{abstract}

Key words: pancreatic neuroendocrine tumors, insulinoma, non-functioning neuroendocrine tumors 


\section{Introduction}

Neuroendocrine tumors (NETs) are a heterogeneous group of tumors with various clinical manifestations and biological behavior. Among the most common neuroendocrine tumors (NETs) are pancreatic neuroendocrine tumors (PNETs) (1). Functioning PNETs produce specific hormonal hypersecretion syndromes. These include: insulinoma, gastrinoma, VIPoma, glucagonoma, and others types of rare tumors like PPoma, adrenocorticotropic hormone (ACTH)oma, growth hormone releasing factor (GRF)oma. However, the majority of PNETs do not produce these syndromes and are therefore classified as non-functioning. Morbidity and mortality are a direct product of their capacity of local invasion and distant spreading (2). Even if they are considered to be relatively rare tumors, more recent studies on NET epidemiology have demonstrated an increasing incidence and prevalence over the past 30 years (3). The majority of PNETs are moderately malignant but they can display a highly variable behavior from nearly benign to extremely aggressive (4). Therapy mainstays for pancreas neuroendocrine neoplasms include surgery and the use of somatostatin analogues.

\section{Material and Methods}

Our case series consist in 18 patients with neuroendocrine pancreatic tumors diagnosed and treated in the Surgery I department of Clinical Hospital Dr. I. Cantacuzino over a 10-year period (2009-2018). We made a retrospective analysis of these patients of their diagnosis particularities and choice of treatment and a review of the existing data in the literature regarding the epidemiology, diagnosis, treatment and prognosis of pancreatic neuroendocrine tumors. We have to mention that another case series represented by 16 patients with pancreatic insulinoma from our clinic was published in 2005 (5).

\section{Results}

18 patients were identified with a mean of age
53 years (limits 28 to 69 ) and a sex ratio male/female of 1 to 1,5 . Out of these 13 were functioning tumors (11 insulinomas and 2 gastrinomas) and 5 nonfunctioning tumors.

The diagnosis was established preoperatively for all the functional tumors and for 2 case out of 5 nonfunctional tumors. Diagnosis was based on symptoms, high levels of insulin or gastrin and imaging studies represented by CT, MRI or SPECTCT which located the tumor. The 2 cases with non-functional NETs were diagnosed also by echo-endoscopic FNA. For the rest of 3 cases with non-functional tumors the initial diagnosis was based on CT or MRI, and the final neuroendocrine tumor diagnosis was established after histopathological examination. At the moment of the diagnosis 2 patients had MEN I syndrome and another one with gastrinoma had a liver metastasis.

The time from the symptoms onset to diagnosis was more than one year for 5 of the patients with insulinoma, all of them with many evaluations including psychiatric treatment. In one case of insulinoma and one with gastrinoma even if the diagnosis was suspected at the onset of symptoms, the tumor was identified only after several years with repeated $\mathrm{CT}$ or MRI.

Most of the tumors were located in the tail of the pancreas (12 cases) the others were located in the body ( 1 cases) and the head of the pancreas (5. cases). 13 patients had tumors of 1-2 cm (all with insulinoma, one with metastatic gastrinoma and one with a nonfunctioning PNET), in 4 cases tumors had 2 to $5 \mathrm{~cm}$ and in one case $11 \mathrm{~cm}$.

Surgical treatment consisted of 10 enucleations (3 of them laparoscopic) and 8 distal pancreatic resections 2 of them associated with splenectomy and in one case a liver metastasectomy was also performed. In the figures below are presented some resections and enucleation specimen (Fig. 1).

Postoperative complications were noted in 5 patients: one postoperative bleeding after a gastrinoma's enucleation which required reintervention and 4 pancreatic fistulas: 2 after 


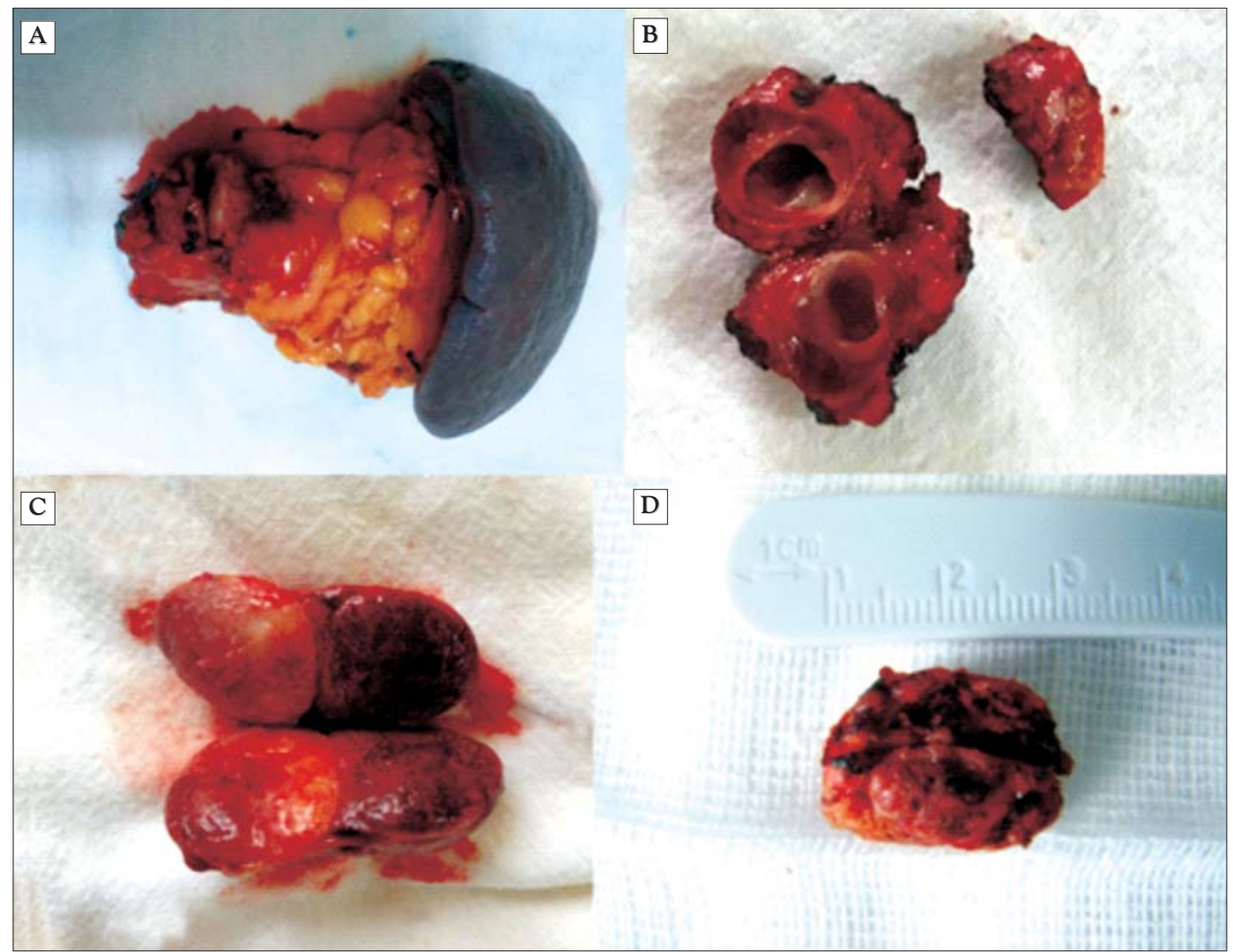

Figure 1. (A) Splenopancreatectomy for PNET specimen; (B) Distal pancreatic resection specimen with NET; (C,D) Specimens after pancreatic insulinoma enucleation

enucleation of one tumor located in the head and one inside the body of the pancreas and the other 2 after distal pancreatic resections. All pancreatic fistulas were treated conservatively and didn't required a reintervention. No deaths were registered. The mean follow-up was 12 months. No local or distant recurrences were found with one exception. One female with an insulinoma of the pancreatic tail was admitted after 8 months with jaundice. Endoscopic sphincterotomy and stent placement were performed followed by a CT scan that revealed a $1.5 \mathrm{~cm}$ tumor in the pancreatic head. Intraoperative a $5 \mathrm{~cm}$ tumor was found and a total duodeno-pancreatectomy was performed. Histopathological examination diagnosis was pancreatic adenocarcinoma.

\section{Discussions}

Neuroendocrine tumors are considered rela- tively rare accounting for $0.46 \%$ of gastrointestinal and bronchopulmonary malignancies, their most frequent localization being the pancreas.Reported incidence in the last decade was less than 1 per 100000 persons per year in population-based studies from Europe and Asia. The incidence and prevalence of NETs are steadily rising in the last 15 years probably due to increased detection by highly sensitive imaging diagnosis methods. Even if in our series a slightly predominance of female was noted studies haven't found a clear difference regarding sex and even when taking into account the patients'race, geographic area, or socioeconomic status (6).

The cellular origin of PNETs is still unclear. Even if the term islet cell tumor was often used to identify PNETs many of them tumors do not develop directly from islet cells. They are originating from APUD stem 
cells, which are pluripotential neuroendocrine cells located within the ductal epithelium of the exocrine pancreas and elsewhere in the distal foregut $(7,8)$

PNETs are classified by their capacity to cause hormonal hypersecretion syndrome as functioning or non-functioning. If functioning PNETs result in hormonal hypersecretion syndromes (Table 1), non-functioning PNETs can be find incidentally on imaging studies or after the histopathological examination because they have no specific symptoms. The main way to differentiate between functioning and non-functioning PNETs is through the patient's clinical presentation. Both functioning and non-functioning PNETs express hormones which show no absolute difference, when analyzed.Both types of hormones, those that are normally expressed by pancreatic islets (insulin, glucagon, somatostatin, and pancreatic polypeptide), and those which are not normally found in pancreatic islets (gastrin, vasoactive intestinal peptide, serotonin, adrenocorticotropin, corticotropin-releasing hormone, parathyroid hormone, growth hormone-releasing hormone, growth hormone, calcitonin) can be secreted by most PNETs, as evidenced by immunochemical examination.(9). These hormones may be biologically inactive or not secreted per se by the tumor. These tumors can however shift their profile over time, changing from non-functioning to functioning, thus triggering a hormonal hypersecretion syndrome (10).

About $90 \%$ of PNETs occur as sporadic

Table 1. Functioning PNET syndromes

\begin{tabular}{ll}
\hline Tumor & Symptom(s) \\
\hline Insulinoma & Hypoglycemia \\
\hline Gastrinoma & Severe peptic ulceration \\
\hline Vipoma & $\begin{array}{l}\text { Watery diarrhea, hypokalemia, } \\
\text { achlorhydria (WDHA syndrome) }\end{array}$ \\
\hdashline Glucagonoma & $\begin{array}{l}\text { Glucose intolerance, necrolytic migratory, } \\
\text { erythema, stomatitis/glossitis, } \\
\text { hypoaminoacidemia }\end{array}$ \\
\hdashline Somatostatinoma & $\begin{array}{l}\text { Hyperglycemia, cholelithiasis, steatorrhea, } \\
\text { achlorhydria }\end{array}$ \\
\hline
\end{tabular}

tumors and approximately $10 \%$ of the different functioning-PNETs occur as part of an inherited syndrome like MEN 1, von Hipple Lindau, von Recklinghausen's syndrome (neurofibromatosis 1), and tuberous sclerosis $(4,11,12)$. If in each of the latter inherited syndromes the patients rarely develop a functioning PNET, MEN1 remains the most important inherited condition responsible for $20-30 \%$ of gastrinoma, $<5 \%$ of insulinomas or other rare types of functioning pancreatic neuroendocrine tumors $(11-14)$.

The clinical diagnosis may be difficult and often delayed because the symptoms of nonfunctioning PNETs are nonspecific and the recognition of hormonal hypersecretion syndrome is not easy requiring considerable clinical experience. In our series the period from the onset of the symptoms to diagnosis was more than a year for all the functioning tumor. In two cases even if the clinical and biological syndrome was present, the localization of the tumor required repeated imaging studies and in one case, even an exploratory laparotomy.

To achieve a full diagnosis the PNET nature and tumor grade should be established, the primary tumor and any existing metastases should be identified, and also the tumor function should be determined. For these are required endocrine testing, imaging and histological evidence. Any incidentally identified pancreatic or liver masses should be biopsied and undergo a histopathological examination in order to confirm the possible NET diagnosis. In the presence of a hormonal hypersecretion syndrome biochemical testing is useful to evaluate the hypersecretion and followed after confirmation by imaging and biopsy (1).

Biochemical testing may be useful to identify subclinical stage of a hormonal hypersecretion. The hormones may also be used for follow-up evaluations as tumor markers. The hormones most commonly produced by the functioning PNETs are insulin, proinsulin, gastrin, glucagon, pancreatic polypeptide (PP) and vasoactive intestinal peptide (VIP) so 
their levels should be measured during a fasting period.

The most useful PNET marker is Chromogranin A (CGA), followed closely by neuron-specific enolase (NSE), and pancreastatin $(15,16)$. However, false positive results may arise in patients suffering from atrophic gastritis and habitual users of antiacids, as they can exhibit higher than normal levels of CGA $(17,18)$.

Imaging studies are necessary for locating and staging of the tumor. In order to gauge the spread of the tumor computed tomography (CT) or magnetic resonance imaging (MRI) are necessary $(19,20)$. Nuclear imaging with octreotide is useful for establishing the tumor affinity for somatostatin and also for the detection of any possible occult tumors which cannot be identified through the use of conventional imaging, and it is recommended to be performed at least once $(21,22)$. FDGPET is useful only for highly aggressive tumors. Most PNETs are negative so that it is not usually indicated $(23,24)$. An extremely sensitive method for detecting small tumors and extra-hepatic metastasis of PNETs is PET with gallium 68-labeled octreotide $(25,26)$. Studies showed a sensitivity from $86-100 \%$, and a specificity from $79-100 \%$ for all PNETs (27-29), with the exception of insulinomas, in which the sensitivity is only $25 \%$ (30). Has been shown that this method of detection can change the tumor management (staging, surgical or medical treatment) in $20-55 \%$ of patients $(31,32)$ and therefore it should be performed in all patients with PNETs except insulinomas

Various TNM classification systems with grading have been developed for neuroendocrine tumors as well as for PNETs: WHO2010 (World Health Organization), ENETs (European Neuroendocrine Tumor Society), AJCC (American Joint Committee on Cancer) These classifications are presented in Table $2(33,34)$.

The grading systems are based on agreed cut-points of mitotic rate and Ki-67 proliferative index and split neuroendocrine tumors into low, intermediate or high grade. These grades are prognostically significant, showing decreased survival as grade increased (35).

Studies has proven, for each of these classifications/grading systems, that they have prognostic value for patients with PNETs. Using of one of these classification/ grading systems is now essential to select the correct treatment for patients and especially for those with aggressive or advanced disease (36).

Minimal Consensus Statement regarding high grade gastroentero-pancreatic neuroendocrine tumors from ENETS guidelines stated that a routine pathological report should include morphology (large cell vs. small cell and differentiation), staining for chromo-

Table 2. Neuroendocrine tumors grading

\begin{tabular}{|c|c|c|c|}
\hline Mitosis & Ki-67\% & ENETS/WHO & Grade \\
\hline$<2$ & $<3$ & NET & 1 \\
\hline $2-20$ & $3-20$ & NET & $\|$ \\
\hline$>20$ & $>20$ & NEC (small cell or large cells) & III \\
\hline \multicolumn{4}{|c|}{ Mixed adenoendocrine carcinoma (MANEC) } \\
\hline \multicolumn{4}{|c|}{ ENETS and AJCC TMN staging for PNET } \\
\hline \multicolumn{2}{|c|}{ ENETS TNM } & \multicolumn{2}{|c|}{ AJCC/UICC TNM } \\
\hline \multicolumn{2}{|c|}{ T1 Limited to pancreas, $<2 \mathrm{~cm}$} & \multicolumn{2}{|c|}{ Limited to pancreas, $<2 \mathrm{~cm}$} \\
\hline \multicolumn{2}{|c|}{ T2 Limited to pancreas, 2-4 cm } & \multicolumn{2}{|c|}{ Limited to pancreas, $>2 \mathrm{~cm}$} \\
\hline \multicolumn{2}{|c|}{$\begin{array}{l}\text { T3 Limited to pancreas }>4 \mathrm{~cm} \text {; } \\
\text { or tumor invasion of duodenum } \\
\text { or common bile duct }\end{array}$} & \multicolumn{2}{|c|}{$\begin{array}{l}\text { Tumor invasion of peripancreatic tissue. } \\
\text { Not involving major vascular invasion } \\
\text { (truncus coeliacus, A. mesenterica superior) }\end{array}$} \\
\hline \multicolumn{2}{|c|}{$\begin{array}{l}\text { T4 Tumor invasion of any adjacent structl } \\
\text { or involving major vascular invasion }\end{array}$} & \multicolumn{2}{|c|}{ Involving major vascular invasion } \\
\hline
\end{tabular}


granin $\mathrm{A}$ and synaptophysin and $\mathrm{Ki}-67$ estimate or/and mitotic count (36).

In the last 10-20 years, a paradigm shift occurred regarding PNETs treatment strategy (37), from a „wait-and-see" to an "aggressive” approach.This shift is based on the assumption that patients will invariably benefit from a reduction of both the primary tumor and the metastases. The increasing popularity of this approach is also based on the increase in the safety in experienced centers.It has 4 compo- $^{-}$ nents: surgery, locoregional therapy, systemic therapy, and complication control (38).

Surgical treatment can achieve: a clinical cure in the case of nonmetastatic tumors, a reduction of hormone secretion through the debulking of liver metastases of functioning PNETs, and also a decrease of the tumor mass effects for all PNET types (1). Surgery is recommended by all guidelines for the patients without life-limiting comorbidities or high surgical risk. Recommendations also stated that symptoms of hormonal excess should be treated with octreotide or lanreotide before surgery. Such treatment is contraindicated in patients with insulinoma because of the risk of lethal outcome (1).

If treatment with octreotide or lanreotide is planned, cholecystectomy is recommended during surgical resection, due to the increased rate of biliary problems associated with longterm use of these agents (39).

For nonfunctioning PNETs the therapeutic approachdepends on tumor localizations and size. For tumors $\leq 2 \mathrm{~cm}$ enucleation with strong consideration of lymph node resection or pancreatectomy (proximal or distal) with or without regional lymph node resection/ splenectomy are indicated. For tumors $>2 \mathrm{~cm}$, pancreatectomy with regional lymph node resection is indicated: Whipple-type or proximal pancreatectomy should be performed in those located in the pancreatic head and distal pancreatectomy with splenectomy for those located distally (40).

Locoregional therapy of unresectable liver metastases include: radiofrequency ablation (RFA), radioactive polymer microspheres, chemoembolization, bland embolization, transcutaneous alcohol ablation, and microwave ablation. These are indicated for most patients with unresectable liver metastases and all have been successfully used $(41,42)$.

For patients with residual disease following surgery and locoregional therapy systemic therapy is a must. In functioning PNETs, especially for VIPoma and glucagonoma, somatostatin analogs are indicated (1). In cases with non-functioning PNETs there is no clear evidence that treatment with somatostatin analogs is effective, but they may restrain tumor growth (43). The somatostatin analogs used are octreotide and lanreotide. These are also available in a long-acting release form. Pasireotide, is a new analog that showed encouraging preliminary results in clinical trials (44). Inall PNET cases with a tumor burden, somatostatin analog treatment is strongly recommended (especially considering the high benefit/risk ratio associated). Everolimus (the mTOR inhibitor) and sunitinib (the tyrosine kinase inhibitor) are another two compounds that studies have shown toprolong progression-free survival by an average of 10 months in patients with well-differentiated PNETs; however, the best indication for these drugs needs further study. Chemotherapy remains reserved for intermediate and high-grade PNETs $(45,46)$.

Common complications and side effects of PNET treatment include: hyperglycemia, malabsorption, various types vitamin deficiencies, and the increased likelihood of cerebral spinal and bone metastases .These complications can be treated by a combination of diet, pancreatic enzyme replacement, insulin necessary, or if the need should arise, external beam radiation therapy $(47,48)$.

Even though the life expectancy of these patients may be significantly reduced when compared to the general population, their prognosis is still better than in the case of patients diagnosed with pancreatic adenocarcinomas. In the case of patients that survive past the 1 year or 5 year mark, life expectancy has a fairly high probability of 
being close to normal.It has long been recognized that the development, presence and extent of liver metastases are one of the most important prognostic factors in patents with $\mathrm{p}$-NETs, however the role of lymph node metastases as a prognostic factor has remained controversial (49).

\section{Conclusions}

As shown in this study, the diagnosis may prove to be a lengthy and difficult process even in the presence of a hormonal hypersecretion syndrome. Nuclear imaging with octreotide is useful for locating the tumor and also for the detection of any possible occult tumors which cannot be identified through the use of conventional imaging.All PNETs should be considered as potentially malignant, and the use of the term "benign" should be particularly avoided, which is why tumor grading based on the mitotic count and Ki-67 index must be established for every case. Surgical treatment is the only with curative potential. It plays and important role even in advanced cases by debulking of liver PNET metastases and reducing the tumor burden.

\section{Author's Contributions}

All authors contributed equally to the manuscript.

\section{Conflict of Interest}

The authors declare no conflicts of interests.

\section{References}

1. Ro C, Chai W, Yu VE, Yu R. Pancreatic neuroendocrine tumors: biology, diagnosis, and treatment. Chin J Cancer. 2013;32(6): 312-324.

2. Massironi S, Sciola V, Peracchi M, Ciafardini C, Spampatti MP, Conte D. Neuroendocrine tumors of the gastro-entero-pancreatic system. World J Gastroenterol. 2008;14(35):5377-84.

3. Modlin IM, Oberg K, Chung DC, Jensen RT, de Herder WW, Thakker RV, et al. Gastroenteropancreatic neuroendocrine tumours. Lancet Oncol. 2008;9(1):61-72.

4. Ehehalt F, Saeger HD, Schmidt CM, Grützmann R, Neuroendocrine tumors of the pancreas.Oncologist. 2009;14(5):456-67.

5. Pătrașcu T, Doran H, Belușică L, Prunaiche M, Goanță A, Vereanu I. Organic hypoglycemia of pancreatic cause. Chirurgia (Bucur) 2003;98(6):509-514.
6. Yao JC, Hassan M, Phan A, Dagohoy C, Leary C, Mares JE, et al. One hundred years after "carcinoid": epidemiology of and prognostic factors for neuroendocrine tumors in 35,825 cases in the United States. J Clin Oncol. 2008;26(18):3063-72.

7. Ong ES, Radhakrishnan N. Neoplasms of the Endocrine Pancreas, Updated: Feb 01, 2018 available at https://emedicine.medscape. com/article/276943.

8. Vortmeyer AO, Huang S, Lubensky I, Zhuang Z, Non-Islet Origin of Pancreatic Islet Cell Tumors, The Journal of Clinical Endocrinology \& Metabolism. 2004;89(4):1934-1938.

9. Kaltsas G, Androulakis II, de Herder WW, Grossman AB Paraneoplastic syndromes secondary to neuroendocrine tumours. Endocr Relat Cancer. 2010;17(3):R173-93.

10. Zhu L, Domenico DR, Howard JM. Metastatic pancreatic neuroendocrine carcinoma causing Cushing's syndrome. ACTH secretion by metastases 3 years after resection of nonfunctioning primary cancer. Int J Pancreatol. 1996;19:205-208.

11. Jensen RT, Berna MJ, Bingham DB, Norton JA. Inherited pancreatic endocrine tumor syndromes: advances in molecular pathogenesis, diagnosis, management and controversies. Cancer. 2008;113 (7 suppl):1807-1843.

12. Ito T, Igarashi H, Uehara H, Berna MJ, Jensen RT. Causes of death and prognostic factors in multiple endocrine neoplasia type 1: a prospective study: comparison of $106 \mathrm{MEN1/Zollinger-Ellison} \mathrm{syn-}$ drome patients with 1613 literature MEN1 patients with or without pancreatic endocrine tumors. Medicine (Baltimore). 2013;92(3): 135-81.

13. Lévy-Bohbot N, Merle C, Goudet P, Delemer B, Calender A, Jolly D, et al. Prevalence, characteristics and prognosis of MEN 1-associated glucagonomas, VIPomas, and somatostatinomas: study from the GTE (Groupe des Tumeurs Endocrines) registry. Gastroenterol Clin Biol. 2004;28(11):1075-81.

14. Thakker RV, Newey PJ, Walls GV, Bilezikian J, Dralle H, Ebeling PR, et al. Clinical practice guidelines for multiple endocrine neoplasia type 1 (MEN1). J Clin Endocrinol Metab. 2012;97(9):2990-3011.

15. Lawrence B, Gustafsson BI, Kidd M, Pavel M, Svejda B, Modlin IM. The clinical relevance of chromogranin $A$ as a biomarker for gastroenteropancreatic neuroendocrine tumors. Endocrinol Metab Clin North Am. 2011; 40(1):111-34, viii.

16. O'Dorisio TM, Krutzik SR, Woltering EA, Lindholm E, Joseph S, Gandolfi AE, et al. Development of a highly sensitive and specific carboxy-terminal human pancreastatin assay to monitor neuroendocrine tumor behavior. Pancreas. 2010;39(5):611-6.

17. Sanduleanu S, De Bruïne A, Stridsberg M, Jonkers D, Biemond I, Hameeteman W, et al. Serum chromogranin A as a screening test for gastric enterochromaffin-like cell hyperplasia during acid-suppressive therapy. Eur J Clin Invest. 2001;31(9):802-11.

18. Peracchi M, Gebbia C, Basilisco G, Quatrini M, Tarantino C, Vescarelli $\mathrm{C}$, et al. Plasma chromogranin $\mathrm{A}$ in patients with autoimmune chronic atrophic gastritis, enterochromaffin-like cell lesions and gastric carcinoids. Eur J Endocrinol. 2005;152(3):443-8.

19. Raman SP, Hruban RH, Cameron JL, Wolfgang CL, Fishman EK. Pancreatic imaging mimics: part 2, pancreatic neuroendocrine tumors and their mimics. AJR Am J Roentgenol. 2012;199(2): 309-18.

20. Debray MP, Geoffroy 0, Laissy JP, Lebtahi R, Silbermann-Hoffman 0 , Henry-Feugeas MC, et al. Imaging appearances of metastases from neuroendocrine tumours of the pancreas. Br J Radiol. 2001; 74(887):1065-70.

21. Krausz Y, Bar-Ziv J, de Jong RB, Ish-Shalom S, Chisin R, Shibley $\mathrm{N}$, et al. Somatostatin-receptor scintigraphy in the management of gastroenteropancreatic tumors. Am J Gastroenterol. 1998;93(1): 66-70.

22. Shi W, Johnston CF, Buchanan KD, Ferguson WR, Laird JD, Crothers JG, et al. Localization of neuroendocrine tumours with (111ln) DTPA-octreotide scintigraphy (Octreoscan): a comparative study with CT and MR imaging. QJM. 1998;91(4):295-301.

23. Adams S, Baum R, Rink T, Schumm-Dräger PM, Usadel KH, Hör G. 
Limited value of fluorine-18 fluorodeoxyglucose positron emission tomography for the imaging of neuroendocrine tumours. Eur $\mathrm{J}$ Nucl Med. 1998;25(1):79-83.

24. Ambrosini V, Tomassetti P, Franchi R, Fanti S. Imaging of NETs with PET radiopharmaceuticals. Q J Nucl Med Mol Imaging. 2010; 54(1):16-23.

25. Krausz Y, Freedman N, Rubinstein R, Lavie E, Orevi M, Tshori S, et al. 68Ga-DOTA-NOC PET/CT imaging of neuroendocrine tumors: comparison with ${ }^{111} 1 \mathrm{n}$-DTPA-octreotide $(0 \mathrm{ctreoScan} \circledast)$. Mol Imaging Biol. 2011; 13(3):583-593.

26. Hofman MS, Kong G, Neels OC, Eu P, Hong E, Hicks RJ. High management impact of Ga-68 DOTATATE (GaTate) PET/CT for imaging neuroendocrine and other somatostatin expressing tumours. J Med Imaging Radiat Oncol. 2012;56(1):40-7.

27. Sharma P, Arora S, Dhull VS, Naswa N, Kumar R, Ammini AC, et al. Evaluation of Ga-DOTANOC PET/CT imaging in a large exclusive population of pancreatic neuroendocrine tumors. Abdom Imaging. 2015;40(2):299-309.

28. Sharma P, Arora S, Mukherjee A, Pal S, Sahni P, Garg P, et al. Predictive value of 68Ga-DOTANOC PET/CT in patients with suspicion of neuroendocrine tumors: is its routine use justified? Clin Nucl Med. 2014;39(1):37-43.

29. Wild D, Bomanji JB, Benkert P, Maecke H, Ell PJ, Reubi JC, et al. Comparison of 68Ga-DOTANOC and 68Ga-DOTATATE PET/CT within patients with gastroenteropancreatic neuroendocrine tumors. J Nucl Med. 2013;54(3):364-72.

30. Sharma $P$, Arora $S$, Karunanithi $S$, Khadgawat R, Durgapal $P$, Sharma R, et al. Somatostatin receptor based PET/CT imaging with 68Ga-DOTA-Nal3-Octreotide for localisation of clinically and biochemically suspected insulinoma. Q J Nucl Med Mol Imaging. 2016;60(1):69-76. Epub 2014 Apr 17.

31. Naswa N, Sharma P, Soundararajan R, Karunanithi S, Nazar AH, Kumar R, et al. Diagnostic performance of somatostatin receptor PET/CT using (68)Ga-DOTANOC in gastrinoma patients with negative or equivocal CT findings. Abdom Imaging. 2013;38(3):552-60.

32. Ilthan H, Fendler WP, Cyran CC, Spitzweg C, Auernhammer CJ, Gildehaus FJ, et al. Impact of Ga-DOTATATE PET/CT on the Surgical Management of Primary Neuroendocrine Tumors of the Pancreas or lleum. Ann Surg Oncol. 2015;22(1):164-71. Epub 2014 Sep 5.

33. Rindi G. Petrone G, Inzani F. The 2010 WHO classification of digestive neuroendocrine neoplasms: a critical appraisal four years after its introduction. Endocr Pathol. 2014;25:186-192.

34. Klimstra DS. Pathology reporting of neuroendocrine tumors: essential elements for accurate diagnosis, classification, and staging. Semin Oncol. 2013:40:23-36.

35. Cavalcanti MS, Gönen M, Klimstra DS. The ENETS/WHO grading system for neuroendocrine neoplasms of the gastroenteropancreatic system: a review of the current state, limitations and proposals for modifications. Int J Endocr Oncol. 2016;3(3):203-219.

36. Falconi M, Eriksson B, Kaltsas G, Bartsch DK, Capdevila J, Caplin $M$, et al. ENETS Consensus Guidelines Update for the Management of Patients with Functional Pancreatic Neuroendocrine Tumors and Non-Functional Pancreatic Neuroendocrine Tumors. Neuroendocrinology. 2016;103(2):153-171.

37. Kvols LK, Revisiting CG. Moertel's land of small tumors. J Clin Oncol. 2008;26:5005-5007

38. Yu R. Radiotherapy: radioactive somatostatin analog therapy against carcinoids. Nat Rev Endocrinol. 2010;6:428-430

39. National Comprehensive Cancer Network. NCCN Clinical Practice Guidelines in Oncology: Neuroendocrine and Adrenal Tumors. NCCN. Available. Version 3.2018 - September 11, 2018; Accessed: December 23, 2018.

40. Evan S Ong, Neuroendocrine Tumors Guidelines Updated: Dec 23, 2018, Available at https://emedicine.medscape.com/article/ 2500010

41. Proye C. Natural history of liver metastasis of gastroenteropancreatic neuroendocrine tumors: place for chemoembolization. World J Surg. 2001;25:685-688

42. Frilling A, Sotiropoulos GC, Li J, Kornasiewicz O, Plöckinger U. Multimodal management of neuroendocrine liver metastases. HPB (Oxford). 2010;12(6):361-79.

43. Sidéris $L$, Dubé $P$, Rinke A. Antitumor effects of somatostatin analogs in neuroendocrine tumors. Oncologist. 2012;17:747-755

44. Kvols LK, Oberg KE, O'Dorisio TM, Mohideen P, de Herder WW, Arnold R, et al. Pasireotide (SOM230) shows efficacy and tolerability in the treatment of patients with advanced neuroendocrine tumors refractory or resistant to octreotide LAR: results from a Phase II study. Endocr Relat Cancer. 2012;19(5):657-66.

45. Raymond E1, Dahan L, Raoul JL, Bang YJ, Borbath I, LombardBohas C, et al. Sunitinib malate for the treatment of pancreatic neuroendocrine tumors. N Engl J Med. 2011;364(6):501-13.

46. Strosberg JR, Fine RL, Choi J, Nasir A, Coppola D, Chen DT, et al. First-line chemotherapy with capecitabine and temozolomide in patients with metastatic pancreatic endocrine carcinomas. Cancer. 2011;117(2):268-75. Epub 2010 Sep 7.

47. Kim SJ, Kim JW, Han SW, Oh DY, Lee SH, Kim DW, et al. Biological characteristics and treatment outcomes of metastatic or recurrent neuroendocrine tumors: tumor grade and metastatic site are important for treatment strategy. BMC Cancer. 2010;10:448.

48. Garcia-Carbonero R, Sorbye $H$, Baudin $E$, Raymond $E$, Wiedenmann B, Niederle B, et al. ENETS Consensus Guidelines for High-Grade Gastroenteropancreatic Neuroendocrine Tumors and Neuroendocrine Carcinomas. Neuroendocrinology. 2016;103(2): 186-94. Epub 2016 Jan 5.

49. Brooks JC, Shavelle RM, Vavra-Musser KN. Life expectancy in pancreatic neuroendocrine cancer. Clin Res Hepatol Gastroenterol. 2019;43(1):88-97 Epub 2018 Sep 13. 